\title{
Bread and Health
}

Kourkouta, L. ${ }^{1}$, Koukourikos, K. ${ }^{2}$, Iliadis, C. ${ }^{3}$, Ouzounakis, P. ${ }^{4}$, Monios, A. ${ }^{5}$ and Tsaloglidou, A. ${ }^{6}$

1. Nursing Department, Alexander Technological Educational Institute of Thessaloniki, Thessaloniki 574 00, Greece

2. Nursing Department, Technological Educational Institute of Thessaloniki, Thessaloniki 574 00, Greece

3. Private Diagnostic Health Center of Thessaloniki, Thessaloniki 54623, Greece

4. General Hospital of Alexandroupoli, Alexandroupoli 68100, Greece

5. 7th High School of Athens, Athens 11634, Greece

6. Nursing Department, Technological Educational Institute of Thessaloniki, Thessaloniki 574 00, Greece

\begin{abstract}
Introduction: Bread is a food full of flavors and nutrients and continues to be the basis of our daily diet. Aim: The aim of this review was the investigation of bread's usefulness in our daily dietary chain and health in general. Material-Method: Extensive review of the recent literature was conducted in electronic databases (Medline, Scopus, and Google Scholar) through the Association of Hellenic Academic Libraries (HEAL-Link) using the appropriate key words: bread, health, disease as well as a combination of them. Results: Bread is an excellent source of complex carbohydrates that provide the body with the energy needed. Although bread is a basic food of everyday human nutrition, it is implicated in a variety of situations that burden the human body, such as obesity. However, this happens only when it is consumed in very large quantities and when it is part of an unbalanced diet. Conclusions: Bread, when is consumed in balanced quantities can give the body plenty of nutrients essential for its good function.
\end{abstract}

Key words: Bread, health, disease.

\section{Introduction}

Bread or in Greek "artos" was considered in the past as the most important human good after health and water. The origin of the term "artos" is ancient Greek: it comes from the verb "ararisko" which means connect, match, put together or "artio" which means brew, and prepare. The modern term "bread" derived from the ancient verb "psoo" meaning rub and it is diminutive of the word "psomys" ( $\rightarrow$ bread $=$ little bit, bite). Its history begins thousands years ago and unfolds in the depths of centuries $[1,2]$.

It belongs to the traditional diet, especially that of the poor. It believed to be the most complete and cheap food and basic auxiliary food in times of extreme food poverty. It is the main food in Europe but also in the cultures of America, Middle East and North Africa,

Corresponding author: Kourkouta Lambrini, Ph.D., professor, research fields: history of nursing, ethics and deontology. unlike East Asia, where the main food is rice [3, 4].

The bread, therefore, a food with awesome variety of flavors and nutrients remains the basis of our daily diet. However, it is accused of contributing to weight gain etc. $[5,6]$.

The purpose of this review is to highlight the importance of using bread in our daily food chain and its contribution to the promotion of our health in general.

\section{Methods}

The search for the sources of this review was made on the Internet from specific databases such as Medline, PubMed, Google Scholar, and the Hellenic Academic Libraries Association (HEAL-Link). The search included research articles of the last, mainly decades, about bread and nutrition, its characteristics, its nutritional value and its advantages. The criterion of exclusion of the articles was language other than Greek and English. The keywords that they used were: bread, health and disease. 


\section{History of Bread}

Known as "the essence of life", bread is already made from 10.000 B.C. at the dawn of Neolithic period and the spread of agriculture, where the seeds were the main ingredient of bread. The first bread in a form similar to the current one is found in Egypt in some of the oldest surviving papyriin which instructions for bread-making process are included. It was also written there that the delay of the pyramids construction was due to insufficient supply of bread to the workers $[7,8]$.

Bread was also widely known in Ancient Greece, where, among other things, the ritual bread called "psadista” was prepared from flour, oil and wine and was offered to the gods. In general, barley bread was produced. Solon also reports that wheaten bread was produced only on festive days. Hesiod, Homer, Herodotus and other important historians and writers have been referred to bread. Moreover, since the 5th century B.C., Athenians could buy bread from bakeries, while in Rome the bakeries just appeared in the 2nd century. Romans were also the ones who created the first ovens in their craft form, especially during the time of Emperor Trajan (87-117 AD), where a mass production of bread was observed [9].

The importance of bread was recognized since that era, a fact reflected in the term "opso/prosfagi” which means the food that one eats with bread, as a supplement used for the rest of the meal [10].

Bread was also used as a symbol in many religions. It is reported in the Old Testament that when Israelites left Egypt and found themselves in the wilderness, God sent them a kind of bread called "manna" and the people survived thanks to it [11]. In the New Testament, the miracle of Christ, in which Christ with five breads and two fish was able to feed five thousand people, is mentioned [12]. Christ also likened himself as bread to his disciples and anyone who could eat it, he would have eternal life. In the Secret Supper Jesus blessed the bread, cut it into pieces and said, "take, eat, that is my body" [13].

The Industrial Revolution (18th-19th century) brought rapid technological breakthroughs and significant changes in bakery. The production of new hard-grained cereals in America made it necessary to create stronger mills than that of watermills and windmills. The construction of roller mills that could grind hard wheat, led to the production of whiter flour. New varieties of wheat promising good quality bread were also studied and discovered. [14]

\section{Bread}

The Code of Food, Beverage and Shared Objects defines as "bread", the product prepared by baking in special furnaces and under defined conditions of mass consisting of wheat flour, water, dough and a small amount of salt (Article 111, 2nd Edition, April 2014). Raw materials used for the bread production available for consumption should meet the terms and provisions of the Code. Where flour from another cereal or a mixture of cereal flour has been used for making bread, this bread must bear the name of such cereals, such as wheat bread with rye [15].

Flour is the main material in making of bread and its properties depend significantly on the properties of the grain from which it is produced. The chemical composition of the flour depends on the degree of milling. Increasing the degree of milling reduces the percentage of starch and increases the components present in the bark such as inorganic ingredients, insoluble fiber and vitamins [16, 17].

Wheat is the only cereal whose flour has the ability to form dough when contacted with water. As a result, flour has the exclusive property of shaping the structure and appearance of bakery products [17].

Flour consists of proteins, starch and other carbohydrate lipids, fiber, water and ash as well as low levels of vitamins, minerals and enzymes [18]. Its proteins, gliadins and glutenins interact with each other when mixed with water creating the gluten grid. The grid has the ability to bind the gases produced during fermentation or produced by chemical blowing agents in the form of bubbles and it swells causing the 
bloating of the dough [9]. The amount of protein contained in the flour determines the amount of gluten to be formed, which, in turn determines the strength, shape and structure of the dough. Hard wheat has higher protein content than soft and therefore the first is used in bread production, as mentioned above [19]. In addition to the proteins that constitute $10-12 \%$ of the flour, most of it consists of starch (70-75\%), while water is about $14 \%$. It is also composed of non-starch polysaccharides (2-3\%), with arabinoxylans and fats at a similar rate. Although at low contents, these ingredients are necessary for the production and quality of the bread [20].

Flour is the main ingredient of bread and creates the grid around which the other ingredients mix in proper proportions to form the dough [21]. The wheat is, furthermore, the only cereal whose flour has the ability to form dough when it comes into contact with water. As a result, the wheat flour has the exclusive property of shaping the structure and appearance of bakery products [17].

\section{Bread's Nutritional Value}

Since bread is a basic food of the daily human nutrition, various attempts have been made to prepare various types of it.

Wheat flour is the main ingredient of bakery. Hard wheat has high protein content and the corresponding flour is used to make bread and other goods, such as croissants, donuts etc. Soft wheat has low protein content and the corresponding flour is used for pastry preparations such as cakes, biscuits, etc. [9]

Some types of bread, such as the whole grain bread, have high fiber content, which enhances the digestive system's action. Rye has the largest amount of dietary fiber and as a result its products have a lower glycemic index compared to wheat products, making them suitable for diabetics [20].

From a nutritional point of view, the barley seed is low in fat, high in dietary fiber and contains essential amino acids in an amount equal to or greater than other cereals. As such, barley flour is a beneficial food for health. In particular, barley b-glucans are proven to reduce blood cholesterol and glycemic load [22-23]. B-glucan, which, as mentioned above, has a positive effect on health, is contained exclusively in barley and no in other cereals. In addition, barley is a source of tocoles (tocopherols and tocotrienols) that they have antioxidant activity [24].

Corn flour is used to produce a variety of bakery products, such as bread, cakes, donuts and other products, most notably baby foods. It has high vitamin A content, almost ten times more than the other cereals, but it is also rich in carotenoids (lutein and zeaxanthin constitute $70 \%$ of carotenoids in corn) that act as antioxidants $[25,26]$.

Whole wheat flour also contains a significant percentage (up to $75 \%$ ) of higher amounts of vitamins, minerals, antioxidants, fiber and other nutrients than that of commonly processed wheat flour, as these components are concentrated in the outer parts of the fruit $[27,28]$.

The increased demand for bread products also contributed to the manufacture of its functional products such as shown in Table 1:

\section{Advantages-Disadvantages of Bread Consumption}

The bread therefore represents an excellent source of complex carbohydrates, which provide the body the energy it needs and play an important role in balancing blood glucose levels [9].

Most types of bread contain low-value, low-fat vegetable protein. They also contain B vitamins, vitamin $\mathrm{E}$ and trace elements such as iron, potassium, calcium and selenium, that are greatly provided in the body. Vitamin B contributes significantly to the protein metabolism and cell replacement, vitamin $\mathrm{E}$ is an active antioxidant, iron is essential for growth and cell oxygenation and potassium for the balanced function of the cells. The calcium contributes to bone density and Selenium is a powerful antioxidant [19]. 
Table 1 Functional bread products.

\begin{tabular}{|c|c|c|}
\hline 1. & $\begin{array}{l}\text { Gluten-free } \\
\text { bread }\end{array}$ & $\begin{array}{l}\text { Celiac disease, also known as gluten sensitization enteropathy, is a systemic autoimmune small bowel disorder } \\
\text { caused by the consumption of cereals (wheat, barley, rye) containing gluten in people with genetic predisposition } \\
\text { [29]. In all cases, and especially in celiac disease, treatment is the lifelong exclusion of gluten from nutrition. } \\
\text { [30]. This created the need to produce gluten-free bread that should have quality features like those of the } \\
\text { common wheat flour. The majority of gluten-free products are of lower quality to that of common wheat flour. } \\
\text { Nutritionally they have lower concentrations of protein and fiber, but also vitamins and minerals [31, 32]. } \\
\text { These products are often also lactose-free (nondairy-basedgluten-freebread), as a large proportion of celiac } \\
\text { patients experience lactose intolerance due to inadequate lactase production from damaged villi of the small } \\
\text { intestine [33]. }\end{array}$ \\
\hline 2. & $\begin{array}{l}\text { Bread with } \\
\text { added fiber }\end{array}$ & $\begin{array}{l}\text { The benefits of dietary fiber to people's health are indisputable. Among these, the most effective glycemic } \\
\text { control, cholesterol control, protection against cardiovascular disease, weight control, bowel function regulation, } \\
\text { and colon cancer protection have been identified [34,35]. According to European legislation (Regulation (EC) } \\
\text { 1924/2006, 2006) the bread is characterized as a product rich in fiber and therefore positively affects the } \\
\text { physiology of the body when it contains at least } 6 \text { g per } 100 \mathrm{~g} \text { of product. Beta-glucans, the water soluble fiber } \\
\text { with high concentration in oats (3-8 g per } 100 \mathrm{~g} \text { dry weight) and barley (2-20 g per } 100 \mathrm{~g} \text { of dry weight), known } \\
\text { for the ability to increase the viscosity of the solutions, are mainly used as functional fibers [36]. }\end{array}$ \\
\hline 3. & $\begin{array}{l}\text { Bread with low } \\
\text { or no added salt }\end{array}$ & $\begin{array}{l}\text { The bread is a rich secret source of sodium. A slice of white, wheat bread ( } 28 \mathrm{~g}) \text { contains } 134 \mathrm{mg} \text { of sodium }(\mathrm{Na}) \text {, } \\
\text { while a slice of rye bread }(28.35 \mathrm{~g}) \text { contains } 171 \mathrm{mg} \text { of sodium }(\mathrm{Na}) \text {. By reducing salt content from the bread, } \\
\text { which is a basic food, the total intake of salt decreases resulting in lowering blood pressure and in the long term, } \\
\text { the decrease of the cardiovascular disease risk [37, 38]. According to European legislation, a food is labeled } \\
\text { "low in salt" when it contains less than } 0.3 \% \text { salt [39]. Bread products with low or no salt addition have been } \\
\text { studied and prepared. The taste of these products differs greatly from the taste of common bread and is not as } \\
\text { enjoyable to consumers as the common bread [40]. }\end{array}$ \\
\hline
\end{tabular}

However, bread is implicated in various conditions that burden the human body, as in the case of obesity. Bread contributes to obesity only when consumed in very large quantities and when it is part of an unbalanced diet. Obesity is also associated with diabetes mellitus [41]. Bread has a high glycemic index, greatly increasing sugar and insulin secretion, which in turn adds to obesity. In a balanced diet, carbohydrates should be about $50 \%$ and 2 slices of whole-wheat bread per day can be conveniently included in the daily diet $[7,20]$.

Gluten, which is contained in bread, causes celiac disease in gluten-sensitive people when they consume bread. They present diarrhea, weight loss, undernutrition, anemia, osteopenia, psychiatric disorders such as irritability and others. These patients should avoid eating grains containing gluten, such as barley, rye, oats and wheat $[42,43]$.

\section{Conclusions}

Bread eaten in balanced quantities not only does not contribute to obesity, but can provide the body with plenty of nutrients essential for its good function. Thus, when incorporated into a generally balanced, nutritious diet, it can play an important role in helping consumers to achieve and maintain the objective of intake of specific calories daily.

Consumers, moreover, require today healthy, but also pleasant pastries. It is necessary to continue research in this field in order to prove the beneficial effects of their action on the body and health in general.

\section{References}

[1] Major Greek Dictionary. 2007. “Tegopoulos Athens: Fitrakis.” ISBN: 978-960-7598-13-4.

[2] Wiktionary. Available at https://el.wiktionary.org/wiki.

[3] McGee, H. 2004. “On Food and Cooking.” New York: Scribner.

[4] ZANNEIO. Available at http://www.zanneio.com/.

[5] Tannahill, R. 1973. "Food in History. Stein and Day." New York. ISBN 13: 9780812814378.

[6] Wikipedia. Available at: https://el.wikipedia.org/

[7] Karnahoriti, Ch. 2016. "Preparation and Quality Evaluation of Functional Cereal Products.” Student thesis. Department of Dietetics and Nutrition Science. Harokopio University. Athens.

[8] Wiktionary. Available at https://en.wiktionary.org.

[9] Psaltakis, G. 2002. “Old Testament.” Volume B 'Exit-Lefkion. Ed. SOTIR. Crop: Exit Book: 16: 12-5, ISBN 978-960-9575-42-3

[10] Trembelas, P. 1974. "The New Testament with a Brief Interpretation.” Ed. SOTIR. Trim: Matthew ID, 19-20, 
ISBN 978-960-9575-38-6

[11] Trembelas, P. 1974. "The New Testament with a Brief Interpretation.” Ed. SOTIR. Crop: Mark ID', 17-25, ISBN 978-960-9575-38-6.

[12] Edwards, W. 2007. "The Science of Bakery Products." RSC Publishing.

[13] Abrahim, S., and Kourkouta, L. 2011. "Hypertension and Nutrition." 4th Panhellenic \& 3rd Pan-European Nursing Congress. Athens.

[14] Kourkouta, L., Rarra, A., and Abrahim, S. E. 2013. "Child Nutrition in School Age.” Scientific Chronicles 18 (2): 78 -82 .

[15] Code of Food, Beverage and Shared Objects. Available at http://www.gcsl.gr/media/trofima/Table-of-Index-July-20 15.pdf

[16] Belitz, H. D., Grosch, W., and Schieberle, P. 2004. Food Chemistry (3rd ed.). New York: Springer-Verlag Berlin Heidelberg.

[17] Hui, Y. 2006. Bakery Products: Science and Technology. Blackwell Publishing.

[18] Giannou, V., Kessoglou, V., and Tzia, C. 2003. "Quality and Safety Characteristics of Bread Made from Frozen Dough." Trends in Food Science and Technology 14 (3): 99-108.

[19] Andrikopoulos, N. 2010. "Food Analysis, Methodology-Organology Theory and Laboratory Exercises." Athens: Bistikea Publications.

[20] Bushuk, W. 2001. Rye: Production, Chemistry, and Technology (2nd ed.). St. Paul. Minnesota: AAOCC.

[21] Pareyt, B., and Delcour, A. J. 2008. "The Role of Wheat Flour Constituents, Sugar, and Fat in Low Moisture Cereal Based Products: A Review on Sugar-Snap Cookies." Critical Reviews in Food Science and Nutrition 48 (9): 824-39.

[22] Abu Mweis, S. S., Jew, S., and Ames, N. P. 2010. "Beta-Glucan from Barley and its Lipid-lowering Capacity: A Meta-analysis of Randomized, Controlled Trials.” Eur. J. Clin. Nutr. 64 (12): 1472-80.

[23] Behall, K. M., Scholfield, D. J., and Hallfrisch, J. 2004. "Diets Containing Barley Significantly Reduce Lipids in Mildly Hypercholesterolemic Men and Women." Am. J. Clin. Nutr. 80 (5): 1185-90.

[24] Cavarello, A., Empilli, S., Brighteni, F., and Stanca, M. 2002. "High (1-3, 1-4)-B-Glucan Barley Fractions in Bread Making and Their Effects on Human Glucaemic Response.” J. Cereal Sci. 39: 59-66.

[25] Gupta, M., Bawa, A. S., and Semwal, A. D. 2011. "Effect of Barley Flour Blending on Functional, Baking and Organoleptic Characteristics of High Fiber Rusks." Journal of Food Processing and Preservation 35 (1): 46-63.

[26] Velu, V., Nagender, A., Prabhakara, G. P., and Rao, G. D.
2006. "Dry Milling Characteristics of Microwave Dried Maize Grains (Zea mays L.)." Journal of Food Engineering 74 (1): 30-6.

[27] Kean, E. G., Hamaker, B. R., and Ferruzzi, M. G. 2008. "Carotenoid Bioaccessibility from Whole Grain and Degermed Maize Meal Products.” Journal of Agricultural and Food Chemistry 56 (21): 9918-26.

[28] Weaver, G. L. 2001. "A Miller's Perspective on the Impact of Health Claims." Nutrition Today 36 (3): 115-8.

[29] Wholegrains Food Fact Sheet. 2013. The British Dietetic Association. UK.

[30] Fasano, A., and Catassi, C. 2012. "Celiac Disease." $N$ Engl J Med. 367 (25): 2419-26.

[31] Fasano, A., and Catassi, C. 2001. "Current Approaches to Diagnosis and Treatment of Celiac Disease: An Evolving Spectrum." Gastroenterology 120 (3): 636-51.

[32] Sciarini, L. S., Ribotta, D. P., Leon, A. E., and Perez, G. T. 2010. "Influence of Gluten-free Flours and Their Mixtures on Batter Properties and Bread Quality." Food and Bioprocess Technology 3: 577-85.

[33] Thompson, T., Dennis, M., Higgins, L. A., Lee, A. R., and Sharrett, M. K. 2005. "Gluten-Free Diet Survey: Are Americans with Coeliac Disease Consuming Recommended Amounts of Fibre, Iron, Calcium and Grain Foods?" Journal of Human Nutrition and Dietetics 18 (3): 163-9.

[34] Gallagher, E., Gormley, T. R., and Arendt E. K. 2004. "Recent Advances in the Formulation of Gluten-free Cereal-Based Products." Trends in Food Science \& Technology 15: 143-52.

[35] Ktenioudaki, A., and Gallagher, E., 2012. "Recent Advances in the Development of High-Fibre Baked Products." Trends in Food Science \& Technology 28 (1): 4-14.

[36] Pereira, M. A., and Ludwig, D. S. 2001. "Dietary Fiber and Body-Weight Regulation. Observations and Mechanisms." Pediatric Clinics of North America 48 (4): 969-80.

[37] Khoury, D. E., Cuda, C., Luhovyy, B. L., and Anderson, G. H. 2012. "Beta Glucan: Health Benefits in Obesity and Metabolic Syndrome." Journal of Nutrition and Metabolism. http://dx.doi.org/10.1155/2012/851362.

[38] FSAI. 2005. "Salt and Health: Review of the Scientific Evidence and Recommendations for Public Policy in Ireland."

[39] Miller, R. A., and Hoseney, R. C. 2008. "Role of Salt in Baking." CFW 53: 4-6.

[40] Commission of the European Communities. 2003. "Proposal for a Regulation of the European Parliament and of the Council on Nutrition and Health Claims Made on Foods."

[41] Rodbotten, M., Tomic, O., Holtekjolen, A. K., Grini, I. S., 
Lea, P., Granli, B. S., Grimsby, S., and Sahlstrom, S. 2015. "Barley Bread with Normal and Low Content of Salt: Sensory Profile and Consumer Preference in Five European Countries." Journal of Cereal Science 64: 176-82.

[42] Kourkouta, L., Prokopiou, E., Frantzana, A., Abrahim, S., and Papastergiou, K. 2012. "Children with Diabetes
Mellitus at School.” Scientific Chronicles 17 (4): 203-8.

[43] Monios, A., Tsaloglidou, A., Koukourikos, K., Dimitriadou, A., Iliadis, C., and Kourkouta, L. 2016. "The Effects of Vitamin E and Exercise on Muscle." International Journal of Health Administration and Education Congress, 229-31. 